\title{
Positive and negative regulation of the gene for transcription factor IIIA in Xenopus laevis oocytes
}

\author{
Kathleen W. Scotto, Hildegard Kaulen, and Robert G. Roeder \\ The Rockefeller University, New York, New York 10021 USA
}

\begin{abstract}
Expression of the positively acting $5 \mathrm{~S}$ gene-specific transcription factor, TFIIIA, is regulated during development, with highest levels of mRNA and protein occurring during oogenesis. By analysis of TFIIIA promoter mutants microinjected into late stage Xenopus oocytes, we have determined DNA sequences required for the transcription of this gene and we have identified proteins that bind to these regulatory sequences. $A$ negative element lies between positions -306 and -289 . Three positive-acting sequences are located between positions -289 and $-253,-250$ and -173 , and -144 and -101 . Gel shift analyses of TFIIIA promoter fragments incubated with Xenopus oocyte extracts have identified two DNA-protein complexes. One complex, designated B1, requires sequences within the promoter region extending from -271 to -253 while the second complex, designated B2, involves promoter sequences from -235 to -221 . The protein involved in formation of the B1 complex has been found to be related to the human adenovirus major late transcription factor, USF.
\end{abstract}

[Key Words: TFIIIA; transcription; cis-acting elements; trans-acting factors; developmental control; Xenopus laevis]

Received February 3, 1989; revised version accepted March 8, 1989.

Regulation of eukaryotic gene expression frequently is achieved at the level of transcription via the interaction of specific proteins with sequence elements located within the promoter region (Maniatis et al. 1987). Quantitative and/or qualitative changes in specific DNAbinding proteins can positively or negatively modulate the temporal and spatial pattern of gene expression during maturation of the organism. The expression of the $5 \mathrm{~S}$ ribosomal RNA genes during the development of the South African clawed toad, Xenopus laevis, has been characterized extensively (Engelke et al. 1980; Korn 1982; Shastry et al. 1982; Wormington et al. 1982) and provides a model system for the analysis of developmental control at the level of transcription. The primary step required for expression of the $5 S$ genes in Xenopus is the binding of a positively acting gene-specific transcription factor, TFIIIA, to the internal control region of the 5S gene (Bogenhagen et al. 1980; Engelke et al. 1980; Bieker and Roeder 1984). TFIIIA binding permits the subsequent formation of a transcription complex involving at least two other transcription factors, TFIIIB and TFIIIC, and RNA polymerase III (Lassar et al. 1983; Bieker et al. 1985). TFIIIA was the first eukaryotic transcription factor that was purified to homogeneity and for which a cDNA was isolated and the corresponding primary amino acid sequence obtained (Ginsberg et al. 1984). On the basis of this sequence, Miller et al. (1985) proposed a TFIIIA structure with several zinc-binding 'fingers' which are involved in DNA binding. This struc- ture has since been identified in other DNA binding proteins (Kadonaga et al. 1988).

The TFIIIA protein serves a dual role in 5S gene expression, acting both as a $5 \mathrm{~S}$ gene-specific transcriptional activator (Engelke et al. 1980) and as a specific RNA-binding protein that interacts with 5S RNA to form the $7 \mathrm{~S}$ ribonucleoprotein storage particle (Honda and Roeder 1980; Pelham and Brown 1980). During the development of $X$. laevis, a distinct pattern of expression of two classes of 5S RNA genes is observed: whereas the somatic $5 \mathrm{~S}$ gene family is expressed in both oocytes and somatic cells, expression of the oocyte $5 \mathrm{~S}$ genes decreases dramatically following oogenesis. Although the differential regulation of the two $5 \mathrm{~S}$ gene classes involves several control mechanisms (Andrews and Brown 1987; Wolffe and Brown 1987, 1988), the demonstration that TFIIIA is required for transcription of both $5 S$ gene families (Engelke et al. 1980) suggests that an alteration in the level or the activity of TFIIIA may play an important role in the regulation of $5 \mathrm{~S}$ gene expression during development.

The expression of the TFIIIA gene in Xenopus has also been shown to be under developmental control. Both TFIIIA protein and steady-state mRNA levels are highest in early oogenesis, decrease significantly in later-stage oocytes, and are reduced drastically during embryogenesis and in somatic cells. Thus, TFIIIA protein levels are reduced from $10^{12}$ to $10^{3}$ molecules per cell, whereas RNA levels are reduced from $10^{6}$ to $<1$ molecules per 
cell during development (Ginsberg et al. 1984; Shastry et al. 1984; Taylor et al. 1986). The high levels of TFIIIA protein in oogenesis appear necessary to ensure full activation of both the oocyte type and the somatic type $5 \mathrm{~S}$ genes as well as stabilization of the RNA product, whereas the low level in somatic cells may be in part responsible for the restriction of activation to somatic genes. An understanding of the mechanism by which TFIIIA gene expression is regulated during Xenopus development would provide insight into an apparent hierarchical network of developmental control in which a gene that encodes a transcriptional regulatory factor is itself regulated in a developmental fashion.

To investigate the process of TFIIIA gene regulation during Xenopus development, we have analyzed the transcription of this gene in oocytes. In this paper we describe the isolation and characterization of a TFIIIA genomic DNA clone and the identification of cis-acting promoter sequences that act both positively and negatively to affect expression of the TFIIIA gene in Xenopus oocytes. Furthermore, using gel retardation assays, we identify DNA-binding proteins that interact with these cis-acting sequences, and we discuss how they may interact to modulate the expression of TFIIIA during development.

\section{Results}

Isolation and characterization of TFIIIA genomic clones

A $X$. laevis genomic library was screened using the TFIIIA cDNA clone, 3al.b, as probe /Ginsberg et al. 1984). A homologous clone containing the $5^{\prime}$ end of the cDNA probe was isolated and characterized further. A gross restriction map of this clone is depicted in Figure 1A. While generally in agreement with the TFIIIA allele described by Tso et al. (1986), restriction analysis of this gene indicates the presence of at least one additional EcoRI site. The 5' end of the mRNA was mapped within a 2.2-kb genomic EcoRI-PstI fragment by primer extension analysis and the region from position -425 (relative to the transcription start site) through the first exon was sequenced (Fig. 1B). This gene lacks the PstI site within the first exon, which is present in the allele described previously by Taylor et al. (1986) and displays heterogeneity in the $5^{\prime}$ leader sequence when compared to the allele described by Tso et al. (1986). A consensus TATA sequence is found at position -32 and a putative CAAT box homology begins at position -94 .

Positive and negative cis-acting elements are involved in TFIIIA gene expression in oocytes

We have begun an analysis of the nature and location of the $5^{\prime}$-flanking sequences that are involved in the transcription of this gene following microinjection into $X$. laevis oocytes (stages V and VI). To facilitate later analysis, we replaced most of the body of the TFIIIA gene with a fragment derived from the human $\beta$-globin gene (Poncz et al. 1983). The chimeric constructs contain a transcription start site derived from the TFIIIA gene in addition to a part of the second and the third exon of the $\beta$-globin gene, including an intron and a functional polyadenylation signal (Fig. 1C).

A set of sequential exonuclease Bal31-generated 5' deletions was constructed within the TFIIIA promoter region; the exact end point of each deletion was determined by DNA sequencing (Fig. 1D). Deletion mutants, along with a marked $X$. laevis histone $\mathrm{H} 4$ gene, were analyzed following coinjection into stage V and VI oocytes. Primer extension of a properly initiated TFIIIA transcript generates a fragment 109 nucleotides in length while the extension product for the $\mathrm{H} 4$ control gene is 181-187 nucleotides in length. The result of a typical analysis is shown in Figure 2A. Figure 2B shows the level of transcription of each deletion mutant relative to the level observed for the $\mathrm{H} 4$ control gene. Each number represents the average of a minimum of four independent experiments. In general, the same pattern of expression was seen whether low $(400 \mathrm{pg}$ ) or high $(2 \mathrm{ng}$ ) concentrations of DNA were injected.

Comparison of the level of expression directed by the -1500 and -306 constructs indicates that sequences downstream of -306 are adequate for efficient expression of the TFIIIA gene, although the possibility of other functional elements occurring upstream of -306 is not necessarily excluded. Deletion of sequences downstream from -306 revealed several major cis-acting elements in addition to the TATA box. Thus, removal of sequences between position -306 and -300 resulted in a substantial increase in transcription from the mutant promoter, indicating the presence of an element which has a negative influence on transcription. Deletion to $-289,-267$, and -265 progressively decreased transcription to the level observed with the wild-type $(-1500)$ promoter. Further deletion through -253 to -235 decreased transcription still further (to about 25\% of control levels). These results indicate the presence of one or more positive cis-acting elements within these regions. It should be noted that in several independent experiments, the -175 deletion mutant promoted a somewhat higher level of transcription than did the -235 mutant, suggesting the presence of another negative element. The $-148,-76$, and -49 deletion mutants directed approximately the same low level of expression; therefore, in the absence of upstream sequence elements, elimination of the putative CAAT box at position -94 by $5^{\prime}$ deletion had no significant effect on transcription. Deletion of the TATA box at position -32 abolishes transcription from the TFIIIA promoter.

To investigate further the region downstream of the cis-acting elements between -306 and -235 , as well as to identify potential cis-acting elements whose function is dependent on the presence of upstream sequences, several internal deletion mutants were constructed using the -306 TFIIIA promoter mutant as a template. Some portion of the deleted sequence was replaced with linker sequence. Analysis of these mutants by microinjection both confirmed and extended the conclusions drawn from the $5^{\prime}$ deletion studies (Fig. 3). Of the nine 


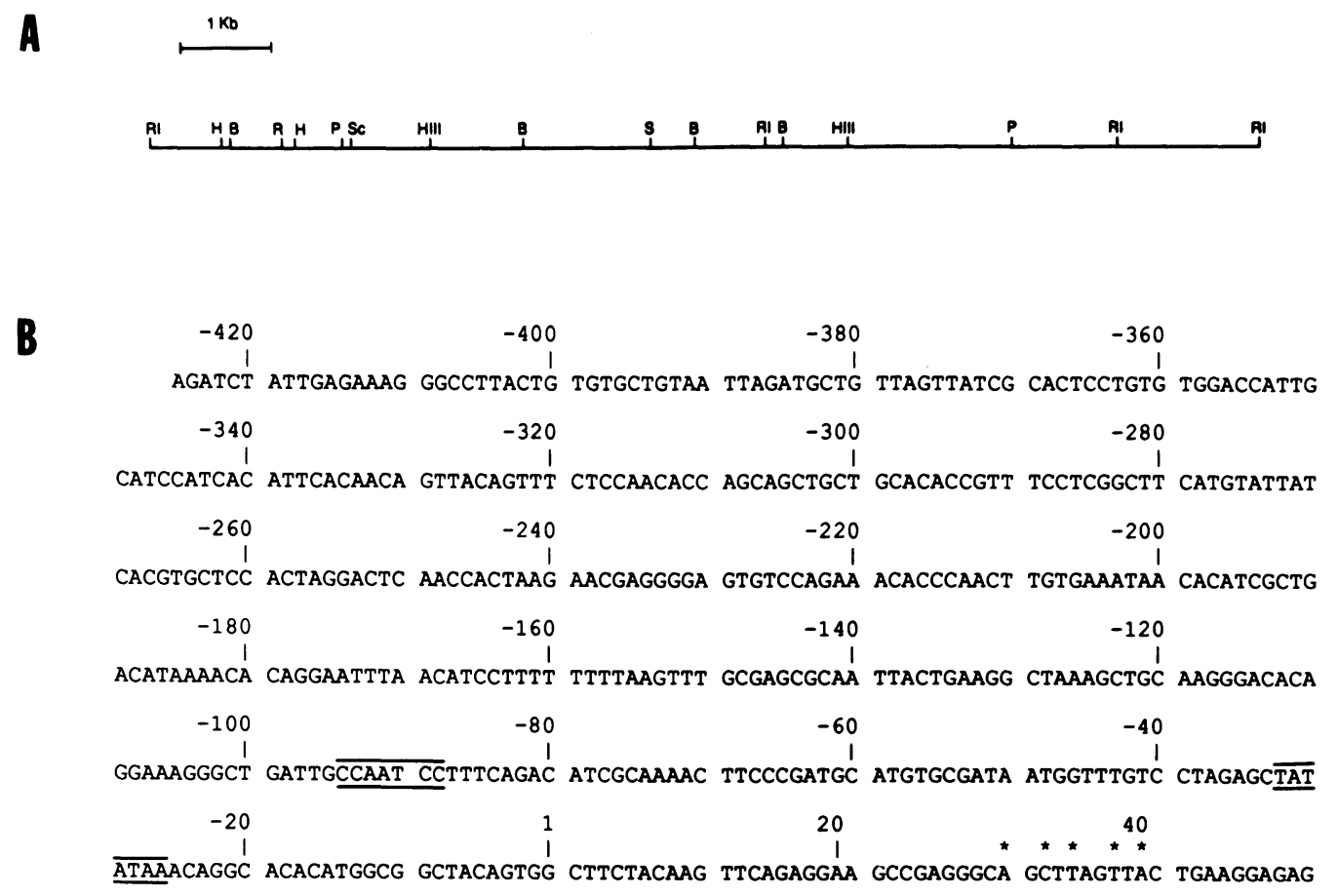

ATG GGA GAG AAG GCG CTG CCG GTG GTG TAT AAG CGG TAC
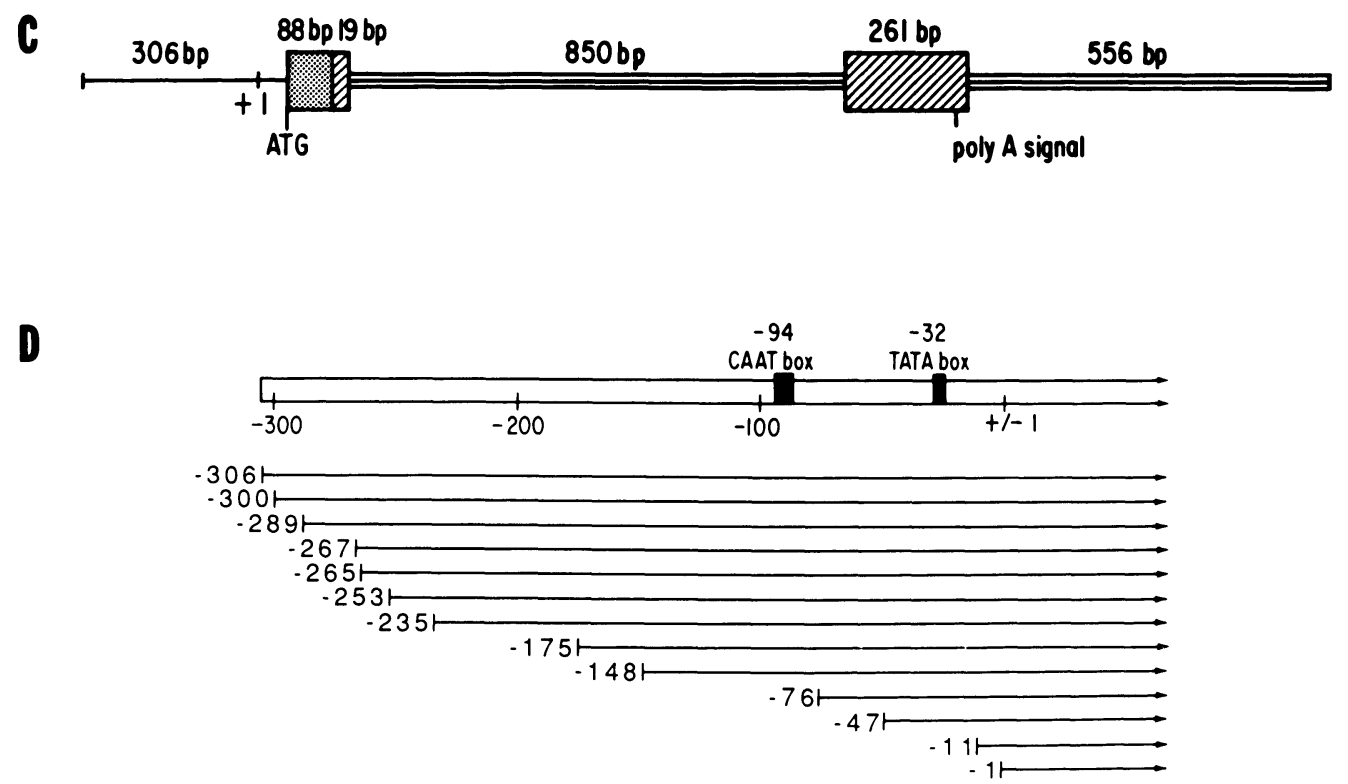

Figure 1. (A) A gross restriction map of the TFIIIA gene showing orientation of the EcoRI fragments within the $\lambda$ genomic clone. Symbols for restriction sites are: (RI) EcoRI; (H) HinfI; (P) PstI; (B) BgIII; (R) RsaI; (Sc) SacI; (HIII) HindIII; (S) SalI. The two EcoRI sites flanking the insert represent artificial linkers added during cloning. The 3 ' end of the gene, as defined by the cDNA clone $3 a 1 . b$, lies in a $3.5-\mathrm{kb}$ EcoRI fragment contained within a second nonoverlapping genomic clone. $(B)$ Nucleotide sequence of the $B g l I I-R s a I$ fragment. The CAAT and TATA boxes are marked. The stars indicate the sequence heterogeneity in the $5^{\prime}$ leader as compared with Tso et al. (1986). (C) Structure of the chimeric TFIIIA/ $\beta$-globin gene. The region of the TFIIIA gene extending from -306 with respect to the transcription start site $(+1$ ) (single line) through +88 within the first exon (stippled box) was fused to a 1689-bp segment of the human $\beta$-globin gene, which extended from a BamHI site within the second exon to a PstI site within the $3^{\prime}$-flanking sequence (striped boxes designate $\beta$-globin exon sequence; the intron sequence appears as a triple line). The TFIIIA ATG and the $\beta$-globin polyadenylation signal are indicated. $(D) 5^{\prime}$ End points of various TFIIIA promoter deletion mutants. Positions of the CAAT and TATA boxes are indicated. 


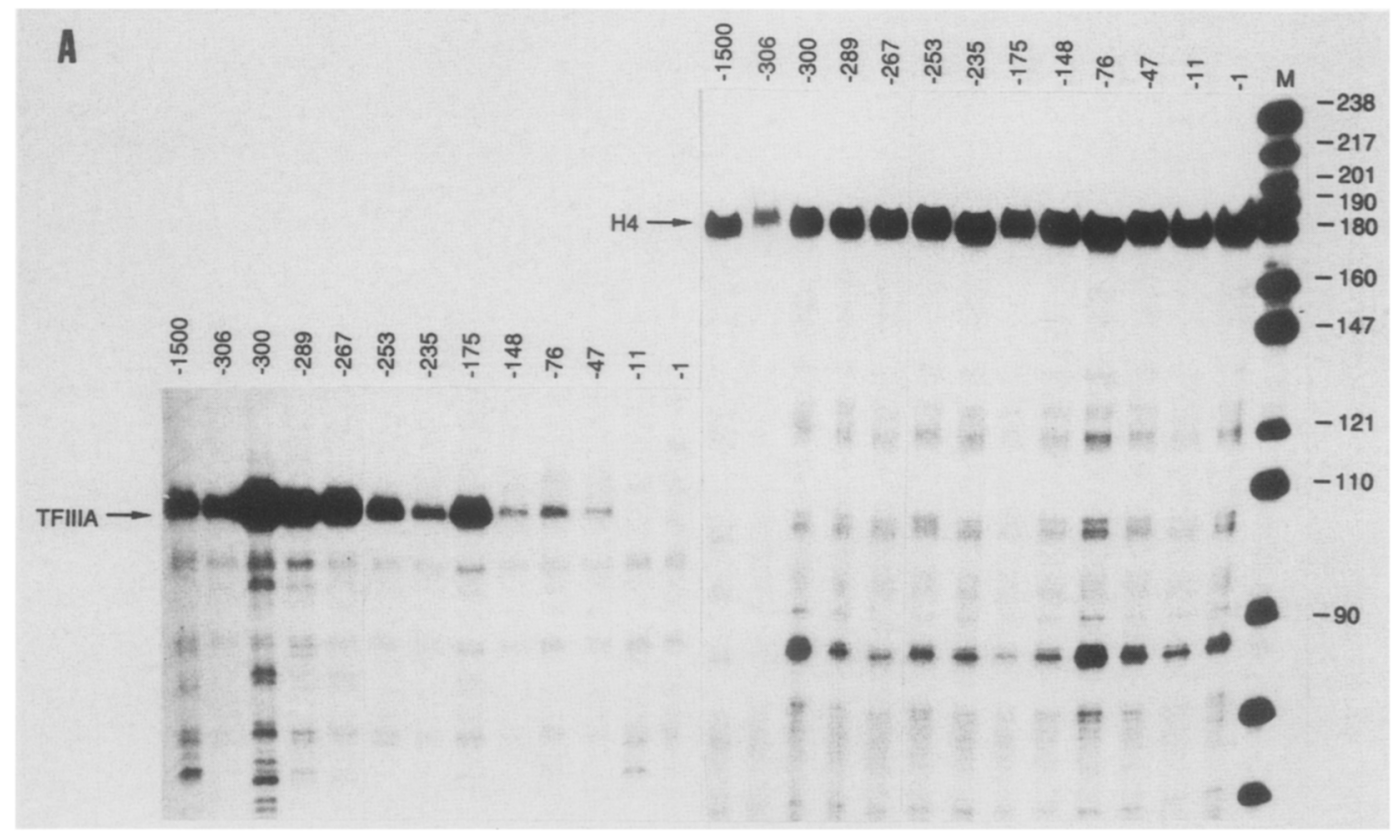

\section{B}

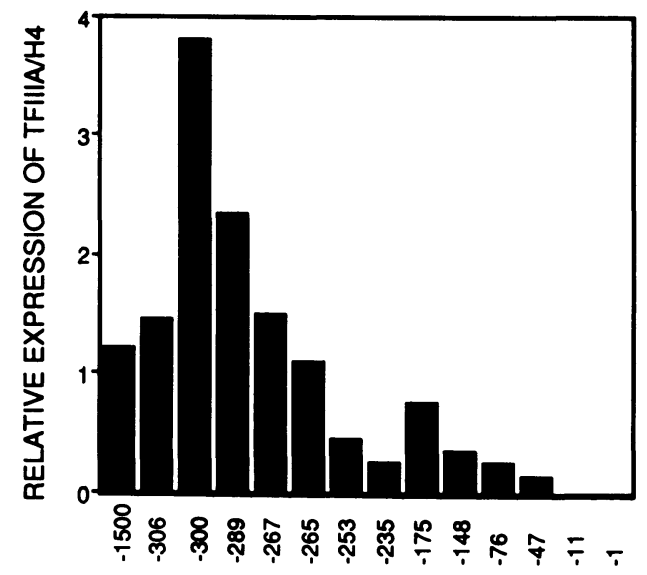

Figure 2. (A) Results of a typical primer extension analysis of total RNA from oocytes microinjected with TFIIIA $5^{\prime}$ promoter deletion mutants. The TFIIIA/ $\beta$-globin extension product is 109 bases long; the $\mathrm{H} 4$ product is 181-187 bases long. The marker $(M)$ is HpaII-digested pBR322. The fragment sizes are given in base pairs. $(B)$ Quantitation is expressed as the ratio between transcription of the deletion mutants and transcription of the $\mathrm{H} 4$ control gene. Each point is an average of at least four independent experiments.

\section{DELETION MUTANTS}

internal deletion mutants (IDM) examined, IDM 4 (-181/-173 deletion), IDM 7 (-75/-58 deletion), and IDM $8(-64 /-48$ deletion) promoted the same level of expression as the -306 deletion mutant, which will be considered wild type in describing the following analyses. Therefore, internal deletion of sequences between -181 and -173 and between -75 and -48 did not affect transcription of the microinjected gene. However, IDM $2(-223 /-173$ deletion) and IDM $3(-214 /-173$ deletion) were transcribed at only $49 \%$ and $53 \%$ of the wild-type levels, respectively, whereas IDM $1 /-250 /-$ 226 deletion) reduced transcription to $17 \%$. Taken together, these data define at least one cis-acting element lying between -250 and -173 within the TFIIIA promoter. Deletion of the region from $-144 /-101$ (IDM 5) reduced transcription to $42 \%$, suggesting the presence of yet another positive-acting element within this region.
Removal of internal sequences containing the CAAT box (IDM 6, -93/-78) reduced transcription approximately twofold, whereas deletion of the region containing the TATA box (IDM 9, $-38 /-4$ ) abolished transcription.

\section{Identification of protein factors that bind within the TFIIIA promoter}

Because much of the expression of the TFIIIA gene in stage $\mathrm{V}$ and VI oocytes was dependent on sequences within the region spanning -306 to -175 , we attempted to identify by gel retardation assays any oocyte proteins that bind within this region. A double-stranded promoter fragment that included sequences from -306 to -180 was labeled and incubated with a crude cellular extract prepared from a whole Xenopus ovary containing 

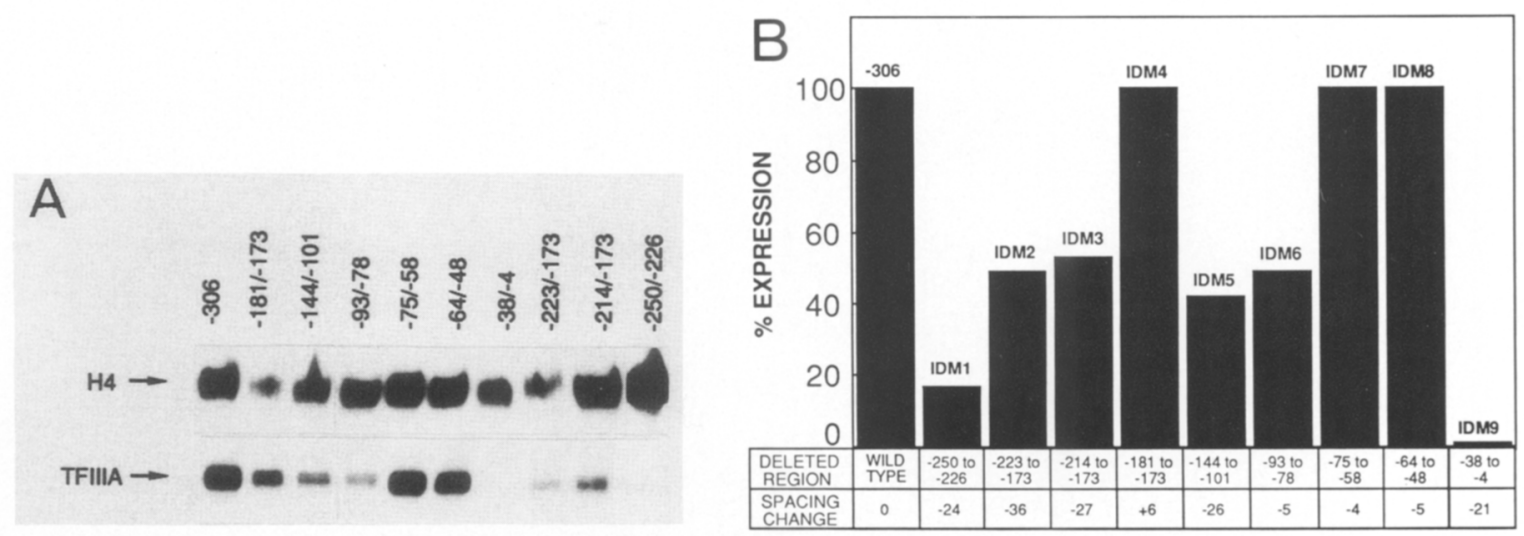

Figure 3. $(A)$ Primer extension analysis of total RNA from oocytes microinjected with mutants containing internal deletions in the TFIIIA promoter. (B) Quantitation of primer extension analyses of IDM. Values represent the percent of transcription of each mutant relative to the wild-type -306 construct and normalized to the expression of the H4 control gene. Sequences deleted and spacing changes generated are shown below the graph. Details on the internal deletion mutants are given in Materials and methods.

oocytes representing all six stages of oogenesis. Following electrophoresis on a $6 \%$ native acrylamide gel, two retarded complexes, designated $\mathrm{B} 1$ and $\mathrm{B} 2$, could be identified (Fig. 4). To prove that the association of these proteins within the TFIIIA promoter was sequence specific and to delimit the regions in which they bind, we tested the ability of various DNA fragments derived from deletion mutants of the TFIIIA promoter to compete for these interactions. A fragment containing promoter sequences extending from -289 to +88 was able to compete for binding of the proteins complexed in both B1 and B2. However, similar fragments with $5^{\prime}$ end points at $-265,-253$, and -235 were able to compete only for the B2 complex. The -175 and -148 deletion fragments were unable to compete for either complex. Additional assays using double-stranded oligonucleotides as competitors (Fig. 5A,B) showed strong competition for the Bl complex with sequences spanning positions -289 to -252 and -271 to -252 and less competion with an oligonucleotide spanning -306 to -265 . The B2 complex was competed with an oligonucleotide containing sequences from -252 to -221 . An oligonucleotide spanning positions -220 to -180 did not compete for either complex. These results indicate that the binding site for the protein involved in the formation of the Bl complex includes the region between -271 and -265 , and that sequences between -265 and -252 stabilize this interaction. The binding site for the $\mathrm{B} 2 \mathrm{com}$ plex lies downstream of -235 and is disrupted or eliminated by removal of sequences between -235 and -221 .

The B1 binding site shares homology with the consensus sequence for the adenovirus major late transcription factor, USF

Analysis of the nucleotide sequence in the region involved in the formation of the B1 complex revealed a partial homology $\left(-2695^{\prime}\right.$-CACGTG-3' -264$)$ to the binding sequence for the adenovirus major late tran- scription factor, USF (Carthew, et al. 1985; Sawadogo and Roeder 1985). Preincubation with an oligonucleotide containing the human USF consensus binding site, 5'-GGCCACGTGACC-3', inhibited formation of the B1 complex, indicating that this sequence is indeed involved in the binding of the B1 protein(s). Competition with a nonspecific oligonucleotide containing an octamer transcription factor -1 binding site (Fletcher et al. 1987) had no effect on the formation of the complex

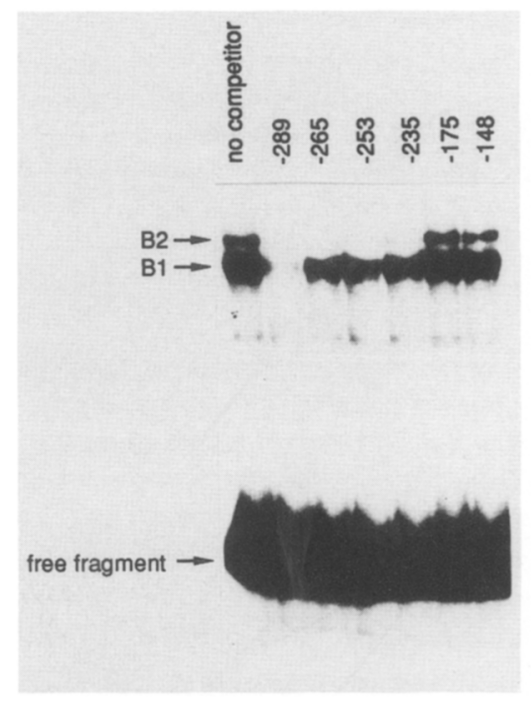

Figure 4. Detection of two prominent DNA binding complexes in $X$. laevis whole ovary extracts. A ${ }^{32} \mathrm{P}$-labeled probe spanning the TFIIIA promoter region from -306 to -180 was incubated with $30 \mu \mathrm{g}$ of whole ovary extract in the standard gel electrophoresis DNA binding assay. Two complexes, designated B1 and B2, could be resolved on a $6 \%$ polyacrylamide gel. Competitor fragments (100 $\mathrm{ng}$; $25-$ to 50 -fold molar excess) were isolated from TFIIIA 5 ' deletion mutants and included sequences from the position indicated at the top of each lane through +88 . 

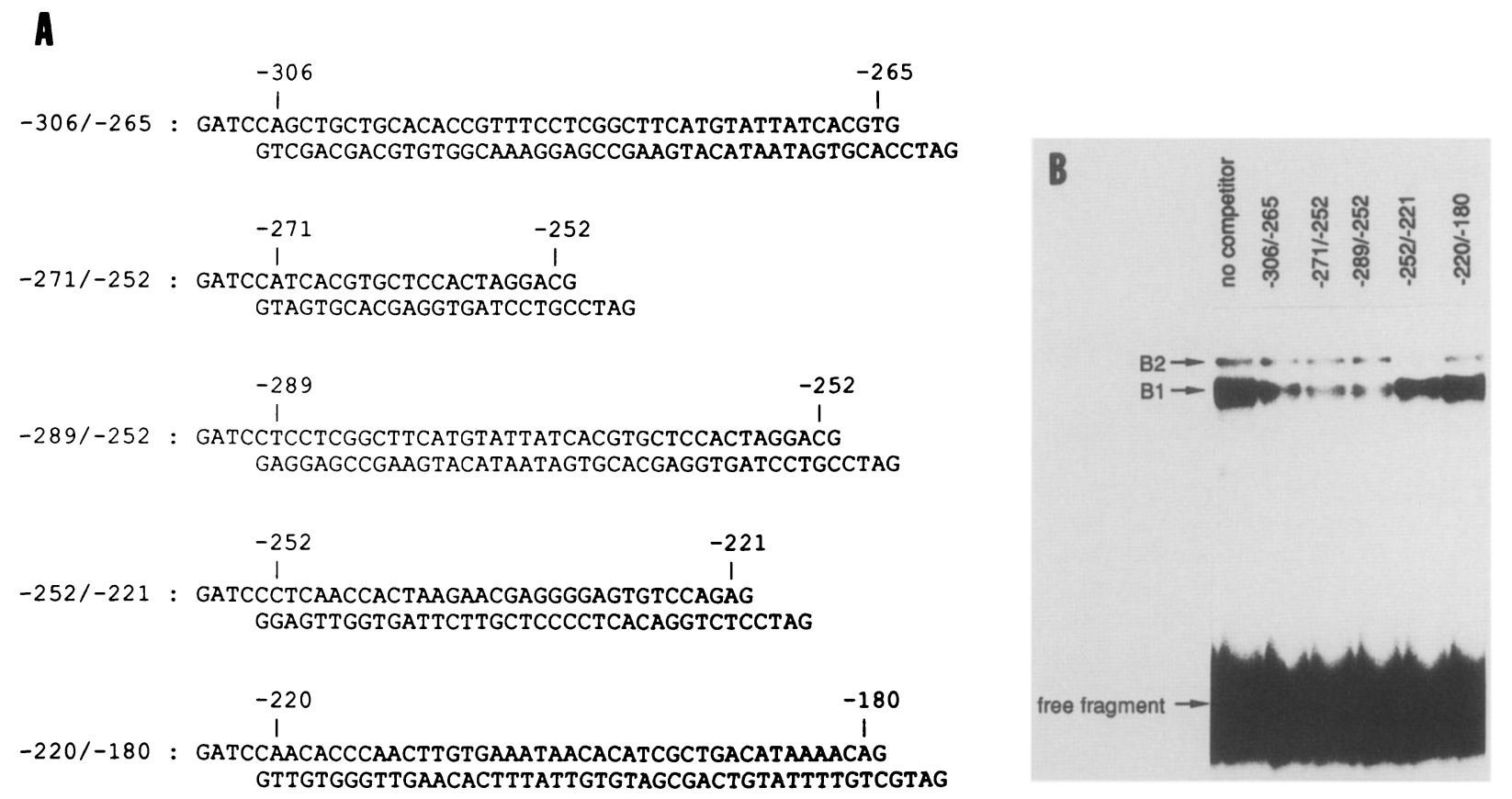

Figure 5. (A) Double-stranded oligonucleotides used as competitors in gel shift analysis. Position within the TFIIIA promoter is shown above each sequence. BamHI restriction sites flank each oligonucleotide. $(B)$ The TFIIIA promoter fragment from -306 to -180 was incubated with $30 \mu \mathrm{g}$ of whole ovary extract under standard gel shift conditions. Competitor oligonucleotides (200 ng) (500to 1500 -fold molar excess/ were added as designated above each lane.

(Fig. 6A). To substantiate further the relationship between the Xenopus B1 complex protein(s) and human USF, a partially purified preparation of USF (the kind gift from M. Sawadogo, Rockefeller University, New York) was substituted for the oocyte extract in a gel shift assay (Fig. 6B). Clearly, the human USF bound to the TFIIIA promoter, generating the two retarded complexes characteristic of the binding of USF to the major late promoter (Sawadogo 1988; Sawadogo et al. 1988). The shifted bands have approximately the same $R_{\mathrm{f}}$ value as does the Bl complex (data not shown).

The region between -235 and -221 (5'-AGGGGAGTGTCCAGA $-3^{\prime}$ ), within which the B2 protein binds, contains a 9- out of 12-bp homology (bases underlined) to the consensus binding sequence for the $\mathrm{NFK}_{\mathrm{K}}$ protein (5'-GGGGACTTTCCG-3') (Sen and Baltimore 1986). However, no competition for B2 complex formation was observed in gel shift analyses with oligonucleotides containing the NFKB consensus sequence, the related binding sequence for the ubiquitous transcription factor H2TF1 (5'-GGGGATTCCCC-3') (Baldwin and Sharp 1987), or the immunoglobulin heavy-chain NTF protein $\left(5^{\prime}\right.$-GGGGGAGGTTCC-3') (B. Yoza and R.G. Roeder, in prep.). Furthermore, purified $\mathrm{NF}_{\kappa} \mathrm{B}$ protein (the kind gift of K. Kawakami, Rockefeller University, New York; Kawakami et al. 1988) did not bind within the $\mathrm{B} 2$ region (data not shown).

Point mutations affect binding of B1 and B2 proteins as well as efficiency of transcription of microinjected constructs

To delineate further the sequences required for forma- tion of the B1 and B2 complexes, as well as to verify the requirement for these sequences in the efficient expression of the TFIIIA promoter in vivo, point mutations were made within the binding regions delimited by the gel shift analyses. In the two mutants analyzed, the $5^{\prime}$ end point was at position -306 . The $\mathrm{B} 1$ promoter mutation is shown in Figure 7A. Microinjection analyses showed that this mutant promoted $45 \%$ of the expression of the wild-type -306 promoter (Fig. 7B). Gel shift analyses using this mutant promoter as competitor showed that although it can compete for binding of the oocyte protein(s) to the wild-type promoter fragment, it does so with a five- to sevenfold reduced efficiency (Fig. $8 \mathrm{~A})$.

The B2 box point mutant (Fig. 7A) was transcribed in oocytes with approximately twofold lower efficiency than the -306 promoter (Fig. 7B). When used as a competitor in gel shift analyses, the B2 mutant promoter was found to compete three- to fivefold less well than the wild-type promoter for the $\mathrm{B} 2$ complex (Fig. 8B).

\section{Discussion}

The regulation of transcription in eukaryotic cells involves the interaction of protein factors with specific DNA promoter sequences. To understand the role that these protein-DNA interactions play in the modulation of gene expression, it is necessary to determine how the expression of the genes encoding transcription factors is regulated. Because the $5 \mathrm{~S}$ gene-specific transcription factor TFIIIA is both regulated developmentally and one of the first eukaryotic factors for which the corre- 

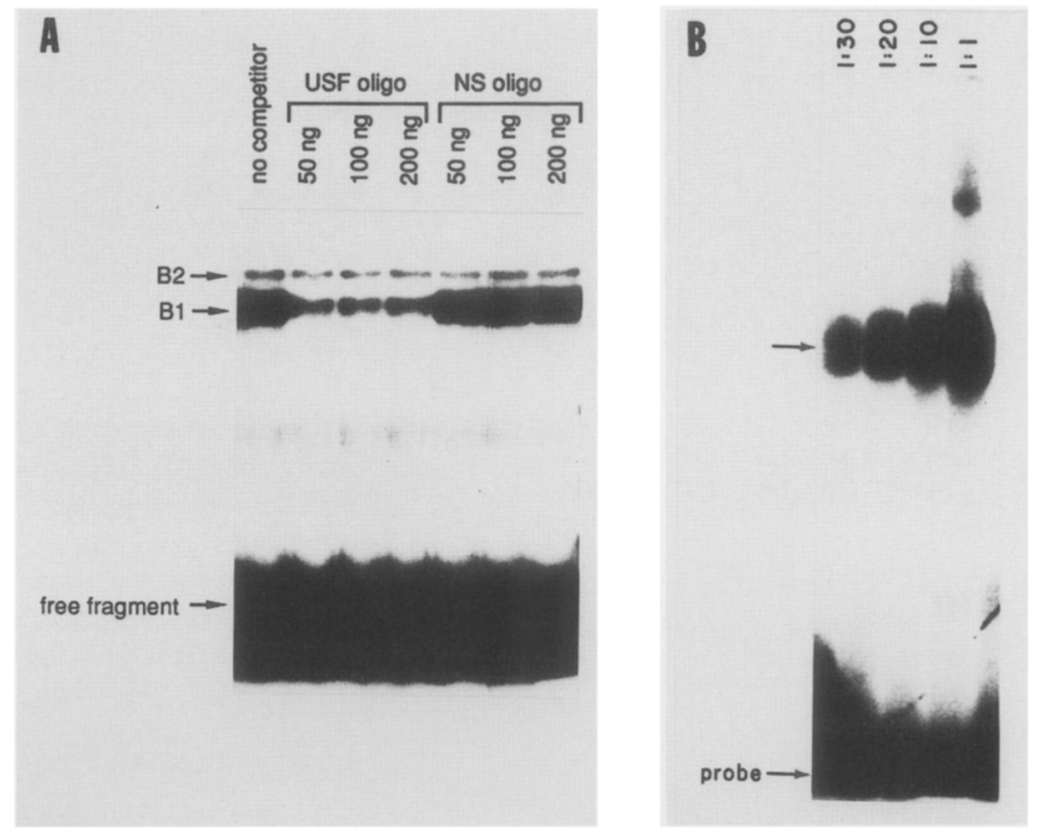

Figure 6. Detection of a USF-related protein in Xenopus whole ovary extract. (A) A USF oligonucleotide competes specifically for the $\mathrm{B} 1$ complex. The standard binding reaction using $30 \mu \mathrm{g}$ of whole ovary extract and ${ }^{32} \mathrm{P}$-labeled probe spanning from -306 to -180 is shown. Competitors included in the reaction mixture are increasing concentrations of a USF oligonucleotide (lanes 2-4) or of a nonspecific oligonucleotide containing an octamer (OTF1) binding site (lanes 5-7) (see Materials and methods for oligonucleotide sequences). (B) Human USF protein binds the TFIIIA promoter sequence. A ${ }^{32}$ P-labeled probe containing sequences from -425 to -253 and various dilutions of a partially purified USF fraction were used in the binding reaction. The shifted complexes appear as a doublet (arrow).

sponding gene has been isolated, it provides an ideal system in which to examine the next level in the hierarchy of transcriptional control. We have defined several elements that are involved in the expression of this gene in late stage oocytes, and have identified two protein factors, potentially important for activation, which bind within these sequences.

TFIIIA alleles exhibit polymorphism, yet are highly conserved throughout the promoter region

Tso et al. (1986) have described previously allelic differences among cloned TFIIIA cDNA and genomic DNA sequences based in part on the presence or absence of a PstI site at position 139 within the protein coding sequence. On the basis of this criterion, the gene described in this report most closely resembles the allele described by Taylor et al. (1986), which lacks a PstI site at position 139. On a gross level, our data further substantiate the proposed allelic heterogeneity, as we have observed differences in at least one additional restriction site between the two genes described. Nucleotide sequence analysis revealed further heterogeneity within the $5^{\prime}$ leader sequence; within 50 bp there are five nucleotide differences between the two alleles.

One negative and three positive cis-acting elements have been defined within the TFIIIA promoter

A functional analysis of the region between -306 and
-173 has implicated at least three distinct and closely spaced sequence elements in the expression of the TFIIIA gene in $X$. laevis oocytes. A negative element lies between -306 and -289 , whereas a positive element lies directly downstream of the negative element and involves sequences from position -289 to -253 . Internal deletions and point mutations in the regions between -250 and -173 and between -144 and -101 reduce transcriptional efficiency, indicating the presence of additional positive-acting elements within these regions. That these latter elements were only detected in analysis of internal deletions or point mutants suggests that upstream promoter regions not present in the $5^{\prime}$ deletion mutants may be required for their activity. We cannot ignore the possibility, however, that effects of internal deletions that have not yet been confirmed by point mutations may result from changes in spacing generated by the deletions. Although removal of the putative CAAT box by $5^{\prime}$ deletion had no appreciable effect on transcription, an internal deletion mutant in which sequences between -93 and -78 , including the CAAT sequence, were removed supported $49 \%$ of wild-type expression; whether this decrease is due to removal of the CAAT box or an adjacent element is presently under investigation. Removal of sequences between -47 and -11 abolishes transcription from the TFIIIA promoter. Because the TATA box is found within this region, we assume that most if not all of this effect results from its removal. Recently, Matsumoto and Korn (1988) reported the identification of two positive elements within the 
A

B1 box mutant:

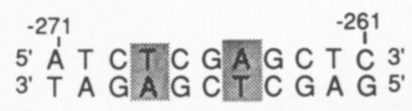

B2 box mutant:
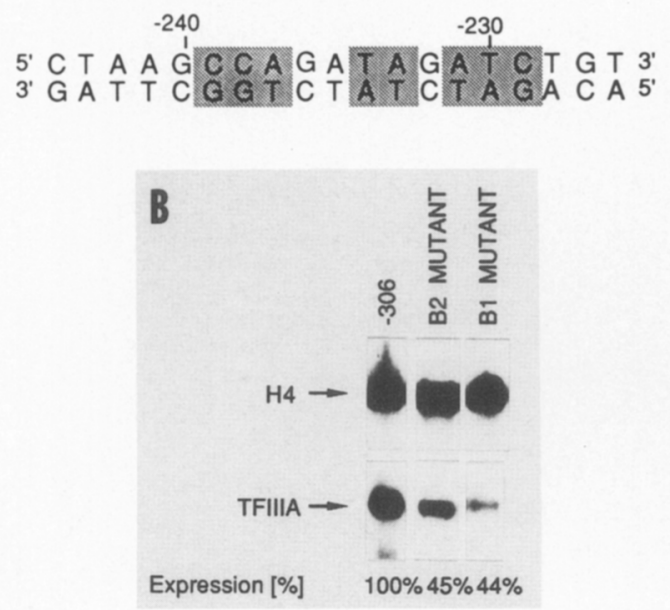

Figure 7. Functional analysis of $\mathrm{B} 1$ box and $\mathrm{B} 2$ box point mutants. (A) Sequence alterations created by site-directed mutagenesis are shown. Altered nucleotides are shaded. $(B)$ Primer extension analysis of B1 and B2 mutant promoters. Percent of relative transcription shown below each lane represents the average of four independent experiments. Percentages were quantitated as described previously.

TFIIIA promoter lying between $-283 /-238$ and $-167 /-122$; the location of the three positive elements defined in our analyses agrees with and extends their observations. A summary of the cis-acting elements within the TFIIIA promoter is depicted in Figure 9.

Two oocyte proteins bind within elements required for the efficient expression of the TFIIIA promoter in oocytes

To define the nature and function of the proteins interacting within the TFIIIA promoter, we have used gel shift assays to identify sequence-specific DNA binding proteins present in $X$. laevis oocyte extracts. To date, we have resolved two DNA-protein complexes, designated B1 and B2, which involve a promoter fragment containing sequences from -306 to -180 . We have shown by competition analysis that the binding of the protein(s) involved in the Bl complex requires sequences between -289 and -252 , a region that is shown to be involved in the activation of this gene in oocytes. Similar analysis of the B2 complex has allowed us to map the binding site for this protein between -235 and -221 within the TFIIIA promoter, a region contained within a second activator element located between
-250 and -173 . Therefore, sequences shown to be required for the in vivo expression of the TFIIIA gene bind proteins, which we assume act as regulators of TFIIIA gene expression.

The protein(s) involved in the formation of the B1 complex is related to the major late transcription factor, USF

It has recently become apparent that, in addition to eukaryotic RNA polymerases (Sentenac 1985), several eukaryotic transcription factors have been highly conserved during evolution (Buratowski et al. 1988). Several mammalian factors have been shown to have homologous counterparts in Xenopus. The Xenopus cytoskeletal actin gene contains a 20-bp homology to the human c-fos serum response element that binds a Xenopus factor homologous to the human serum response factor (Mohun et al. 1987). Doebbeling et al. (1988) have identified a cell-specific activator region within the Xenopus A2 vitellogenin gene that is active transcriptionally in rat liver nuclear extracts. A Xenopus histone $\mathrm{H} 4$ transcription factor, XH4TF1, is most likely homologous to the human histone $\mathrm{H} 4$ transcription factor H4TF2 /G.H. Thomsen and R.G. Roeder, in prep.). Emerson and Roeder (1984) have shown that Xenopus and human RNA polymerase III factors are interchangable in functional assays. The relationship we have identified between the Xenopus B1 protein and the human major late transcription factor extends these observations.

The major late transcription factor, USF (Sawadogo and Roeder 1985) or MLTF (Carthew et al. 1985) was identified initially by its ability to bind selectively to and activate transcription from the adenovirus major late promoter. More recently, it has been found to bind to and activate cellular genes, such as the rat $\gamma$-fibrinogen promoter (Chodosh et al. 1987) and the mouse metallothionein I gene promoter (Carthew et al. 1987). USF-related proteins also have been reported in yeast (Bram and Kornberg 1987). We have found that the $X$. laevis oocyte protein involved in the formation of the B1 complex is similar in size and binding properties to the human USF protein, binding to a 6-bp core CACGTG of the 12-bp adenovirus major late sequence; the resulting complex migrates with a similar $R_{\mathrm{f}}$ value as does the complex formed between the Xenopus-DNA fragment and the human USF protein (data not shown). Recently, it has been demonstrated that polyclonal mouse antibodies raised against human USF (Sawadogo et al. 1988) interact with the Bl complex in a gel shift assay, resulting in a second shift with lower electrophoretic mobility (H. Kaulen, unpubl.). Whether the Xenopus protein is functionally similar to the human protein awaits purification and in vitro analysis. However, the location of its binding site over $260 \mathrm{bp}$ upstream of the start site of transcription suggests that if its function involves interaction with TFIID, as has been suggested for the major late USF (Sawadogo and Roeder 1985), bending of the DNA molecule is likely involved in the juxtapositioning of these two proteins. 

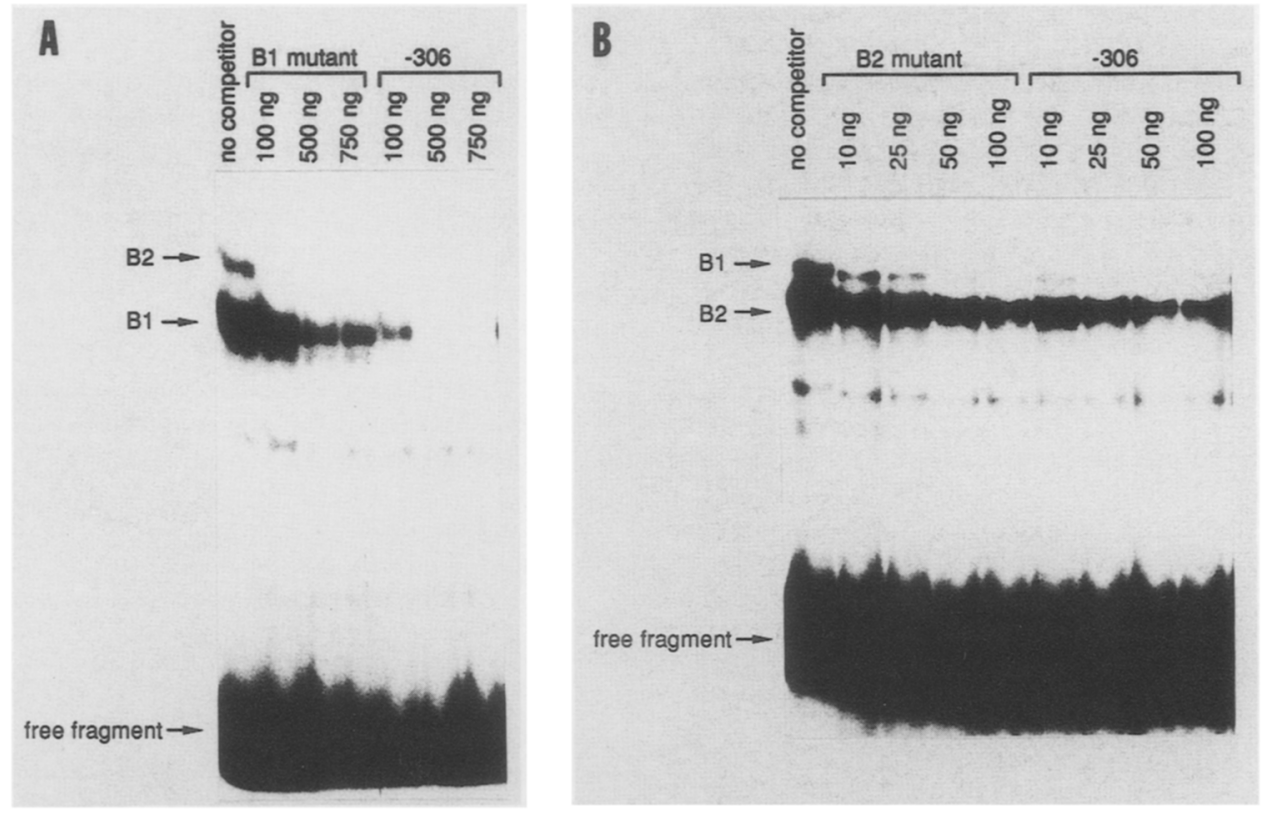

Figure 8. (A) Gel shift analyses of oocyte extracts using a $-306 /-180$ fragment as probe under standard reaction conditions. Competitor DNAs used were linearized plasmids containing either the -306 promoter with mutations in the B1 box or the unmodified -306 promoter. Numbers above each lane indicate increasing amounts of competitor used. In both cases, $100 \mathrm{ng}$ corresponds to a fourfold molar excess of promoter sequence. $(B)$ Gel shift analyses of oocyte extracts using a $-306 /-180$ fragment as probe. Competitor DNAs used were linearized plasmids containing either the -306 promoter with mutations in the B2 box or the unmodified - 306 promoter. Numbers above each lane indicate increasing amounts of competitor used. For each competitor used, $50 \mathrm{ng}$ corresponds to a twofold molar excess of promoter sequence.

\section{Developmental regulation of the TFIIIA gene-a perspective}

In X. laevis, TFIIIA gene expression is regulated developmentally, with highest levels occurring during the maturation of the oocyte; the regulation of this gene-specific transcription factor has been implicated in the regulation of the Xenopus $5 \mathrm{~S}$ gene family. Regulation of TFIIIA gene expression may itself be modulated by changes in the interplay of various constitutive and regulatory transcription factors within the promoter elements throughout development. It is interesting to speculate how the closely spaced positive and negative cis-acting elements within the TFIIIA promoter may be occupied differentially by factors during Xenopus development. A model to explain the regulation of the TFIIIA gene would involve a decrease in the binding of activators and an increase in the binding of repressor/silencers during development, because of either quantitative or qualitative changes in the transcription factors. This model is similar to the mechanism described for regulation of the $\beta$-interferon gene, in which a negative regulatory element in proximity to a constitutive transcriptional element binds a factor that is released on induction (Goodbourn et al. 1986; Zinn and Maniatis 1986). We are continuing our search for trans-acting factors involved in the expression of this gene and will determine whether the modulation of these proteins throughout oogenesis, embryogenesis, and in somatic cells is involved in the regulation of the TFIIIA gene.

\section{Materials and methods}

Cloning and characterization of the TFIIIA gene

A Xenopus genomic library constructed in EMBL4 using partial Sau3A-digested high-molecular-weight DNA was the kind gift of D. Melton (Harvard University). The library was screened with the TFIIIA cDNA 3al.b (Ginsberg et al. 1984) using standard techniques (Maniatis et al. 1982). Two clones were analyzed further and the TFIIIA transcription unit contained

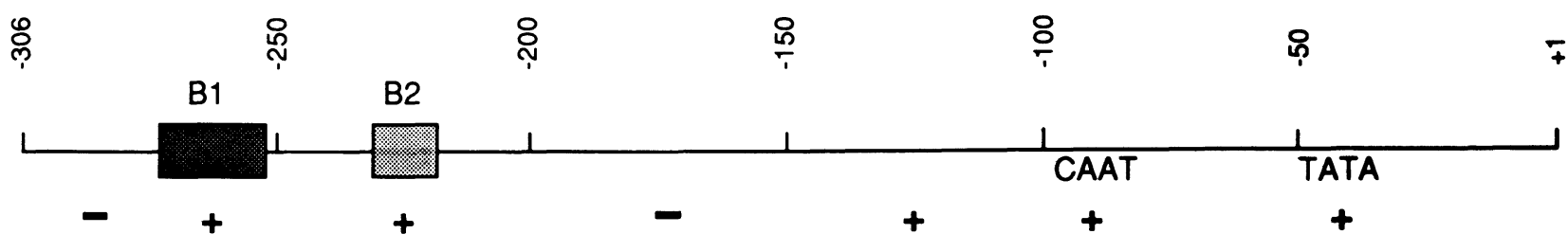

Figure 9. Cis-acting elements in the TFIIIA promoter. 
therein was oriented relative to subclones of the $3 a$ al.b cDNA. Previous primer extension analysis (Ginsberg et al. 1984) allowed us to map the $5^{\prime}$ end of the cDNA within a genomic 2.2 kb EcoRI-PstI fragment, which was subcloned into pUC 12 or 13 , or $M 13 \mathrm{mp} 8$ or $M 13 \mathrm{mp} 9$, prior to nucleotide sequencing. Unless otherwise noted, all restriction enzymes used for these and subsequent analyses were obtained from either New England Biolabs, Bethesda Research Laboratories, or BoehringerMannheim Biochemicals, and reactions were carried out according to suppliers' specifications.

\section{Construction of $5^{\prime}$ deletion mutant chimeric genes}

The pUC 13 plasmid containing the 2.2-kb EcoRI-PstI fragment was linearized by digestion with $B g I I I$. Sequential deletions were generated using the exonuclease $B a l 31$ and conditions recommended by the vendor (IBI). Following digestion, the ends were repaired with the Klenow fragment of DNA polymerase I and EcoRI linkers were added at the deletion end points. EcoRI-RsaI fragments extending from the $5^{\prime}$ deletion end point through $88 \mathrm{bp}$ of the first TFIIIA exon were sized by gel electrophoresis, isolated, and subcloned into EcoRI-SmaIdigested pUC 13. The end points of the $5^{\prime}$ deletion mutants were determined in a sequencing reaction using the chain-termination method and Sequenase reagents (U.S. Biochemical Corp.).

TFIIIA/ $\beta$-globin chimeric genes were constructed by joining each promoter deletion mutant to a 1689-bp BamHI-PstI fragment derived from the human $\beta$-globin gene (Poncz et al. 1983) containing part of the second and all of the third exon of the $\beta$-globin gene, including the second intervening sequence and a polyadenylation signal.

\section{Cloning of the internal deletion mutants}

The $3^{\prime}$ promoter deletion mutants were constructed following the same general strategy as described above. A pUC 13 plasmid containing $306 \mathrm{bp}$ of the TFIIIA promoter region was digested with BamHI and treated with Bal31 exonuclease (IBI). BamHI linkers were ligated to the truncated 3 ' ends of the TFIIIA promoter. EcoRI-BamHI fragments of varying size were isolated and subcloned into EcoRI-BamHI-digested pUC 13.

Suitable $5^{\prime}$ and $3^{\prime}$ promoter mutants in pUC 13 were chosen for cloning of the internal deletion mutants. The 3' mutants were digested with $\mathrm{BamHI}$, and the $5^{\prime}$ overhanging ends were filled in with DNA polymerase I Klenow fragment and recut with HindIII, a polylinker restriction site close to the BamHI site. The 5' deletions were digested with EcoRI, filled in, and redigested with HindIII. The EcoRI-HindIII fragments were gel-purified and ligated to the $3^{\prime}$ mutants prepared as described. All internal deletion mutants were confirmed by sequence analysis. For IDM 2, IDM 3, and IDM 4, the deletion end points were separated by a 14-bp synthetic linker, $15^{\prime}$-CGGGATCAATTCCT-3'). IDM 5 contains a 19-bp insertion (5'CGGGATCAATTCCACAGGC-3'); 13 bp were provided by a synthetic linker and $6 \mathrm{bp}$ are due to a rearrangement at the target sequence during cloning. IDM 6, IDM 7, IDM 8, and IDM 9 contain a 13-bp synthetic linker sequence (5'-CGGGATCAATTCC-3'). In some cases, the inserted sequence restored the original promoter sequence, which was taken into account when calculating the spacing change.

\section{Site-directed mutagenesis}

The point mutants in the B1 and B2 boxes and IDM 1 were constructed using the site-directed mutagenesis protocol of
Kunkel et al. (1987), with minor modifications. A TFIIIA promoter fragment including sequences from -306 to +88 was subcloned into the vector pEMBL19, which contains an $\mathrm{f} 1$ origin of replication and can be used to generate single-stranded templates (Dente et al. 1985). The recombinant plasmid was transformed into the Escherichia coli dut $^{-}$ung $^{-}$strain BW313 (Kunkel 1985). Following superinfection with $\mathrm{fl}$ phage, singlestranded DNA was purified for use in subsequent mutagenesis procedures. The oligonucleotides used to produce the $\mathrm{B} 1$ box mutation contained the sequence $-280 \quad 5^{\prime}$-TCATGTATTATCTCGAGCTCCACTAGGAC-3' -252 ; the B2 box mutant oligonucleotide included the sequence $-2535^{\prime}$-ACTCAACCACTAAGCCAGATAGATCTGTCCAGAAACACCC$3^{\prime}-214$ (altered bases are underlined). The internal deletion IDM $1(-250$ to -226$)$ was created using oligonucleotides flanking the deletion site. Sequenase (U.S. Biochemical Corp.) replaced T4 DNA polymerase in the in vitro synthesis reactions. Mutations were verified by nucleotide sequencing.

\section{Microinjection experiments in stage $V$ and VI $\mathrm{X}$. laevis oocytes}

Ovaries were obtained from large adult female $X$. laevis purchased from either Nasco (Fort Atkinson, Wisconsin) or Xenopus (Michigan). Individual stage V and VI oocytes (staged according to Dumont 1972) were teased from the ovary and stored in MSB-H buffer [88 mM NaCl, $1 \mathrm{mM} \mathrm{KCl}, 2.4 \mathrm{mM}$ $\mathrm{NaHCO}_{3}, 0.82 \mathrm{mM} \mathrm{MgSO}, 0.33 \mathrm{mM} \mathrm{Ca}\left(\mathrm{NO}_{3}\right)_{2}, 0.41 \mathrm{mM} \mathrm{CaCl}$, $10 \mathrm{mM}$ HEPES (pH 7.6), $10 \mathrm{mg} / \mathrm{ml}$ of penicillin, $10 \mathrm{mg} / \mathrm{ml}$ of streptomycin] for several hours up to 4 days prior to use. Subsequent microinjections and incubations were performed in MSB-H buffer. For each TFIIIA promoter mutant analyzed, a $X$. laevis histone $\mathrm{H} 4$ gene, into which a 9-bp HindIII linker was inserted for identification (G. Thompsen, Rockefeller University, New York) was coinjected as a control; $400 \mathrm{pg}$ or $2 \mathrm{ng}$ of both the control and mutant plasmid DNA in $10 \mathrm{nl}$ or $40 \mathrm{nl}$ of $\mathrm{H}_{2} \mathrm{O}$, respectively, were injected into the germinal vesicles of 25-50 oocytes. Injected oocytes were incubated for $20 \mathrm{hr}$ at $23^{\circ} \mathrm{C}$, then harvested for further analysis.

\section{Isolation of RNA from microinjected oocytes}

Surviving oocytes $(75-100 \%)$ were collected, pooled, and washed several times in TE buffer [10 mM Tris $(\mathrm{pH} 8.0), 1 \mathrm{~mm}$ EDTA , then homogenized in an extraction buffer containing $10 \mathrm{~mm}$ Tris (pH 7.6), $10 \mathrm{~mm} \mathrm{NaCl}, 10 \mathrm{~mm}$ EDTA, 0.5\% SDS, and $0.14 \mathrm{mg} / \mathrm{ml}$ Proteinase $\mathrm{K}$ and incubated for $1 \mathrm{hr}$ at $37^{\circ} \mathrm{C}$. Following incubations, samples were brought to $0.3 \mathrm{M}$ sodium acetate and extracted several times with phenol, phenol/chloroform, and chloroform. The RNA was precipitated, recovered by centrifugation, and resuspended in $10 \mu \mathrm{l}$ of $\mathrm{H}_{2} \mathrm{O}$ per oocyte equivalent prior to quantitation. Between 3 and $5 \mu \mathrm{g}$ of total RNA was recovered per oocyte. RNA integrity was monitored by agarose gel electrophoresis prior to analysis.

\section{Primer extension experiments}

Primer extension analyses were performed in primer excess, using 1.5 oocyte equivalents of total RNA for analysis of TFIIIA gene expression $(5-7 \mu \mathrm{g})$, and 0.5 oocyte equivalents of RNA for analysis of transcription of the control $\mathrm{H} 4$ gene $(1.5-2.5 \mu \mathrm{g})$, and $3 \mathrm{ng}\left(1 \times 10^{5}\right.$ to $\left.2 \times 10^{5} \mathrm{cpm}\right)$ of the appropriate primers. Synthetic oligonucleotides corresponding to a region of exon 2 of the human $\beta$-globin gene and spanning a synthetic modification introduced in the histone $\mathrm{H} 4$ gene were radioactively labeled with T4 polynucleotide kinase and $\left[\gamma^{32} \mathrm{P}\right]$ ATP. Neither primer was found to cross-hybridize to any endogenous oocyte 
transcript. Extension of the 26-base globin primer on a properly initiated transcript generates a 109-base fragment. The $\mathrm{H} 4$ primer is 34 bases and the resulting extension product is 181-187 bases long; this heterogeneity is due to multiple start sites (G. Thompsen, pers. comm.). RNA and primer were heated to $80^{\circ} \mathrm{C}$ for $2 \mathrm{~min}$ and incubated for $2 \mathrm{hr}$ at $65^{\circ} \mathrm{C}$ (globin primer) or $55^{\circ} \mathrm{C}$ (histone $\mathrm{H} 4$ primer) in a hybridization buffer containing $0.4 \mathrm{M} \mathrm{NaCl}, 40 \mathrm{~mm}$ PIPES (pH 6.5), and $1 \mathrm{~mm}$ EDTA. Specific RNA was elongated in $50 \mathrm{~mm}$ Tris (pH 8.3), $10 \mathrm{~mm}$ $\mathrm{MgCl}_{2}, 40 \mathrm{mM} \mathrm{KCl}, 5 \mathrm{~mm}$ DTT, $0.2 \mu \mathrm{g}$ of actinomycin D, 0.2 $\mathrm{mM}$ dNTPs, 45 units RNase inhibitor (RNasin, BoehringerMannheim), and 5-10 units AMV reverse transcriptase (Boehringer-Mannheim) at $42^{\circ} \mathrm{C}$. The reaction was stopped by heating to $70^{\circ} \mathrm{C}$ for $10 \mathrm{~min}$. The RNA was degraded with DNase I-free RNase A and the elongation product was precipitated, resuspended in sequencing dye, and electrophoresed through an $8 \%$ sequencing gel. Signals were quantitated by scintillation counting.

\section{Preparation of total ovary extract}

Oocytes were released from whole ovaries by gentle rotation in a solution of $0.3 \%$ collagenase IA (Sigma), prepared in MSB-H, for $12 \mathrm{hr}$ at $23^{\circ} \mathrm{C}$. Following extensive washing with MSB-H, the oocytes were washed in TE (pH 8.0), and lysed by 4 strokes of a Kontes all-glass Dounce homogenizer (B-type pestle). The lysis buffer contained $50 \mathrm{~mm}$ Tris (pH 8.4), $170 \mathrm{mM} \mathrm{KCl}, 0.2$ mM EDTA, 20\% glycerol, $0.5 \mathrm{~mm}$ DTT, and $0.5 \mathrm{~mm}$ PMSF. The extract was centrifuged at $100,000 \mathrm{~g}$ at $4^{\circ} \mathrm{C}$ for $1 \mathrm{hr}$. Aliquots of the supernatant were quick-frozen and stored at $-70^{\circ} \mathrm{C}$ prior to use. Protein concentrations were determined according to Bradford (1976).

\section{Gel shift assays}

Gel shift assays were performed according to Garner and Revzin (1981) with some modifications: $1 \mathrm{ng}$ of a ${ }^{32} \mathrm{P}$-labeled DNA fragment was incubated with $4 \mu \mathrm{g}$ of poly[d(I-C)], $30 \mu \mathrm{g}$ of oocyte protein, and competitor DNA where indicated in a buffer containing $25 \mathrm{mM}$ HEPES (pH 7.9), $10 \mathrm{~mm} \mathrm{MgCl}_{2}, 1 \mathrm{~mm}$ DTT, $0.1 \mathrm{~mm} \mathrm{CaCl}, 60 \mathrm{mM} \mathrm{KCl}$, and $10 \%$ glycerol at room temperature for $15 \mathrm{~min}$. The reaction mixture was electrophoresed through a $6 \%$ polyacrylamide gel in $1 \times$ TBE $(89 \mathrm{mM}$ Tris, $89 \mathrm{~mm}$ boric acid, $2 \mathrm{mM} \mathrm{Na}{ }_{2}$ EDTA). The five TFIIIA promoter oligonucleotides used as competitors contained sequences between $-306 /-265,-289 /-252,-271 /-252,-252 /-221$ and $-220 /-180$; each oligonucleotide was flanked with a BamHI restriction site. The USF oligonucleotide used as competitor contained the sequence 5'-CCGAATTCCTGGCCACGTGACCGCAGCTGT-3'. The nonspecific oligonucleotide competitor, which included a binding site for the human histone H2B octamer protein, contained the sequence $5^{\prime}$ AATTCCACCACCTGGGTAATTTGCATTTCTG-3' (Fletcher et al. 1987). Assays in which the human USF protein was substituted for the oocyte extracts were performed as described by Sawadogo et al. (1988). The human USF protein, kindly provided by $M$. Sawadogo, was a partially purified fraction following chromatography on Mono Q, as described by Sawadogo et al. (1988).

\section{DNA techniques}

All DNA manipulations were done using standard techniques (Maniatis et al. 1982) and according to the National Institutes of Health (NIH) guidelines.

\section{Acknowledgments}

We thank Dr. D.A. Melton for providing the $X$. laevis genomic DNA library, and Dr. A.M. Ginsberg for isolation of the genomic clone. We are grateful to Drs. Kevin C. Gorman and Eckart Bartnik for assistance in the preparation of the figures, to M.C. Gleich for technical assistance, and to Dr. Gerald H. Thomsen and the members of the Roeder laboratory for helpful scientific discussion. This work was supported by Public Health Service grant CA-2567 from the NIH to R.G.R. and by general support from the Pew Charitable Trusts. K.W.S. was supported in part by an American Cancer Society fellowship (PF-2648) and by a National Research Service Award from the $\mathrm{NIH}$ (GM-10777). H.K. was supported by a postdoctoral fellowship from the German Research Foundation.

\section{References}

Andrews, T. and D.D. Brown. 1987. Transient activation of oocyte 5S RNA genes in Xenopus embryos by raising the level of the trans-acting factor TFIIIA. Cell 51: 445-453.

Baldwin, A.S. and P.A. Sharp. 1987. Binding of a nuclear factor to a regulatory sequence in the promoter of the mouse $\mathrm{H}-2 \mathrm{~K}^{\mathrm{b}}$ class I major histocompatibility gene. Mol. Cell Biol. 7: 305-313.

Bieker, J.J. and R.G. Roeder. 1984. Physical properties and DNA-binding stoichiometry of a $5 \mathrm{~S}$ gene-specific transcription factor. J. Biol. Chem. 259: 6158-6164.

Bieker, J.J., P.L. Martin, and R.G. Roeder. 1985. Formation of a rate-limiting intermediate in $5 \mathrm{~S}$ gene transcription. Cell 40: 119-127.

Bogenhagen, D.F., S. Sakonju, and D.D. Brown. 1980. A control region in the center of the 5S RNA gene directs specific initiation of transcription. II. The $3^{\prime}$ border of the region. Cell 19: 27-35.

Bradford, M.M. 1976. A rapid and sensitive method for quantification of microgram quantities of protein utilizing the principle of protein-dye binding. Anal. Biochem. 72: 248254.

Bram, R.J. and R.D. Kornberg. 1987. Isolation of a Saccharomyces cerevisiae centromere DNA binding protein, its human homolog and its possible role as transcription factor. Mol. Cell. Biol. 7: 403-409.

Buratowski, S., S. Hahn, P.A. Sharp, and L. Guarente. 1988. Function of a yeast TATA element binding protein in a mammalian transcription system. Nature 334: 37-42.

Carthew, R.W., L.A. Chodosh, and P.A. Sharp. 1985. An RNA polymerase II transcription factor binds to an upstream element in the adenovirus major late promoter. Cell 43: 439448.

Carthew, R.W., L.A. Chodosh, and P.A. Sharp. 1987. The mouse major late transcription factor binds to and activates the mouse metallothionein I promoter. Genes Dev. 1:973-980.

Chodosh, L.A., R.W. Carthew, J.C. Morgan, G.R. Crabtree, and P.A. Sharp. 1987. The adenovirus major late transcription factor activates the rat $\gamma$-fibronectin gene. Science 238: 684-689.

Dente, L., M. Sollazzo, C. Baldari, G. Cesarini, and R. Cortese. 1985. The pEMBL family of single-stranded vectors. In DNA cloning: a practical approach, vol. I. (ed. D.M. Glover), pp. 101-107. IRL Press, Oxford.

Doebbeling, U., K. Ross, L. Klein-Hitpass, C. Morley, U. Wagner, and G.U. Ryffel. 1988. A cell-specific activator in the Xenopus A2 vitellogenin gene: promoter elements functioning with rat liver nuclear extracts. EMBO J. 7: 24952401. 
Dumont, J. 1972. Oogenesis in Xenopus laevis (Daudin); stages of oocyte development in laboratory maintained animals. $J$. Morph. 136: 153-180.

Engelke, D.R., S-Y. Ng, B.S. Shastry, and R.G. Roeder. 1980. Specific interaction of a purified transcription factor with an internal control region of 5S RNA genes. Cell 19: 717-728.

Emerson, B.M. and R.G. Roeder. 1984. DNA sequences and transcription factor interactions of active and inactive forms of mammalian 5S RNA genes. I. Biol. Chem. 259: 79267935.

Fletcher, C., N. Heintz, and R.G. Roeder. 1987. Purification and characterization of OTF1, a transcription factor regulating cell cycle expression of a human histone $\mathrm{H} 2 \mathrm{~b}$ gene. Cell 51: 731-741.

Garner, M.M. and A. Revzin. 1981. A gel electrophoresis method for quantifying the binding of proteins to specific DNA regions. Application to the components of the E. coli lactose operon regulatory system. Nucleic Acids Res. 9: 3047-3060.

Ginsberg, A.M., B.O. King, and R.G. Roeder. 1984. Xenopus 5S gene transcription factor TFIIIA: characterization of a cDNA clone and measurements of RNA levels throughout development. Cell 39: 479-489.

Goodbourn, S., H. Burstein, and T. Maniatis. 1986. The human $\beta$-interferon gene enhancer is under negative control. Cell 45: $601-610$.

Honda, B.M. and R.G. Roeder. 1980. Association of a 5 S gene transcription factor with 5S RNA and altered levels of the factor during cell differentation. Cell 22: 119-126.

Kadonaga, J.T., A.J. Courey, J. Ladika, and R. Tjian. 1988. Distinct regions of $\mathrm{Spl}$ modulate DNA binding and transcriptional activation. Science 242: 1566-1570.

Kawakami, K., C. Scheidereit, and R.G. Roeder. 1988. Identification and purification of a human immunoglobulin enhancer binding protein NFKB that activates transcription from a human immunodeficiency virus (HIV-1) promoter in vitro. Proc. Natl. Acad. Sci. 85: 4700-4704.

Korn, L. 1982. Transcription of Xenopus 5S ribosomal RNA genes. Nature 295: 101-105.

Kunkel, T.A. 1985. Rapid and efficient site-specific mutagenesis without phenotypic selection. Proc. Natl. Acad. Sci. 82: $488-492$.

Kunkel, T.A., J.D. Roberts, and R.A. Zakow. 1987. Rapid and efficient site-specific mutagenesis without phenotypic selection. Methods Enzymol. 154: 367-382.

Lassar, A.B., P.L. Martin, and R.G. Roeder. 1983. Transcription of class III genes: formation of preinitiation complexes. Science 222: 740-748.

Maniatis, T., E.F. Fritsch, and J. Sambrook. 1982. Molecular cloning: a laboratory manual. Cold Spring Harbor Laboratory, Cold Spring Harbor, New York.

Maniatis, T., S. Goodbourn, and J.A. Fischer. 1987. Regulation of inducible and tissue specific gene expression. Science 236: $1237-1245$.

Matsumoto, Y. and L. Korn. 1988. Upstream sequences required for transcription of the TFIIIA gene in Xenopus oocytes. Nucleic Acids Res. 16: 3801-3815.

Miller, J., A.D. McLachlan, and A. Klug. 1985. Repetitive zincbinding domains in the protein transcription factor IIIA from Xenopus. EMBO I. 4: 1609-1614.

Mohun, T., N. Garrett, and R. Treisman. 1987. Xenopus cytoskeletal actin and human c-fos gene promoters share a conserved binding site. EMBO J. 6: 667-673.

Pelham, H. and D.D. Brown. 1980. A specific transcription factor that can bind either the 5S RNA gene or 5S RNA. Proc. Natl. Acad. Sci. 77: 4170-4174.
Poncz, M., E. Schwartz, M. Ballantine, and S. Surrey. 1983. Nucleotide sequence analysis of the $\gamma \beta$-globin gene region in humans. J. Biol. Chem. 258: 11599-11609.

Sawadogo, M. and R.G. Roeder. 1985. Interaction of a gene-specific transcription factor with the adenovirus major late promoter upstream of the TATA box region. Cell 43: 165-175.

Sawadogo, M. 1988. Multiple forms of human gene specific transcription factor USF. II. DNA binding properties and transcriptional activity of the purified HeLa USF. J. Biol. Chem. 263: 11994-12001.

Sawadogo, M., M.W. Van Dyke, P.D. Gregor, and R.G. Roeder. 1988. Multiple forms of the human transcription factor USF. I. Complete purification and identification of USF from HeLa cell nuclei. J. Biol. Chem. 263: 11985-11993.

Sen, R. and D. Baltimore. 1986. Multiple nuclear factors interact with the immunoglobulin enhancer sequence. Cell 46: 705-716.

Sentenac, A. 1985. Eukaryotic RNA polymerases. CRC Critical Rev. in Biochem. 18: 33-90.

Shastry, B.S., B.M. Honda, and R.G. Roeder. 1984. Altered levels of $5 \mathrm{~S}$ gene specific transcription factor TFIIIA during oogenesis and embryonic development. I. Biol. Chem. 259: 11373-11382.

Taylor, W., I.J. Jackson, N. Siegel, A. Kumar, and D.D. Brown. 1986. The developmental expression of the gene for TFIIIA in Xenopus laevis. Nucleic Acids Res. 15: 6185-6195.

Tso, J.Y., D.J. Van den Berg, and L. Korn. 1986. Structure of the gene for Xenopus transcription factor TFIIIA. Nucleic Acids Res. 8: 5473-5505.

Wolffe, A.P. and D.D. Brown. 1987. Differential 5S RNA gene expression. Cell 51: 733-740.

1988. Developmental regulation of two $5 \mathrm{~S}$ ribosomal RNA genes. Science 241: 1626-1632.

Wormington, W.M., M. Schlissel, and D.D. Brown. 1982. Developmental regulation of Xenopus 5S RNA genes. Cold Spring Harbor Symp. Quant. Biol. 47: 879-884.

Zinn, K. and T. Maniatis. 1986. Detection of factors that interact with the human $\beta$-interferon regulatory region in vivo by DNase I footprinting. Cell 45: 611-618. 


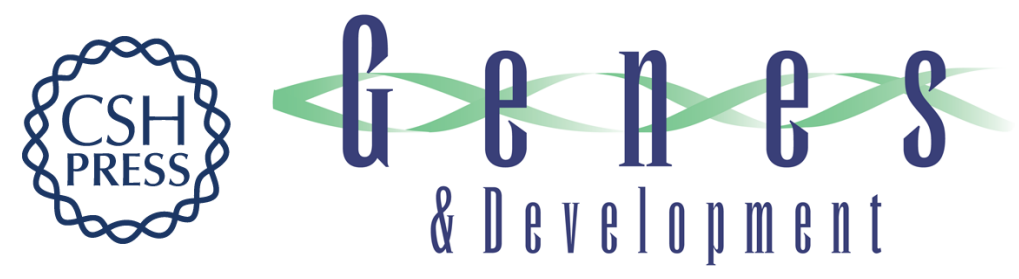

\section{Positive and negative regulation of the gene for transcription factor IIIA in Xenopus laevis oocytes.}

K W Scotto, H Kaulen and R G Roeder

Genes Dev. 1989, 3:

Access the most recent version at doi:10.1101/gad.3.5.651

$\begin{array}{ll}\text { References } & \text { This article cites } 44 \text { articles, } 17 \text { of which can be accessed free at: } \\ \text { http://genesdev.cshlp.org/content/3/5/651.full.html\#ref-list-1 }\end{array}$

License

Email Alerting Receive free email alerts when new articles cite this article - sign up in the box at the top Service right corner of the article or click here.

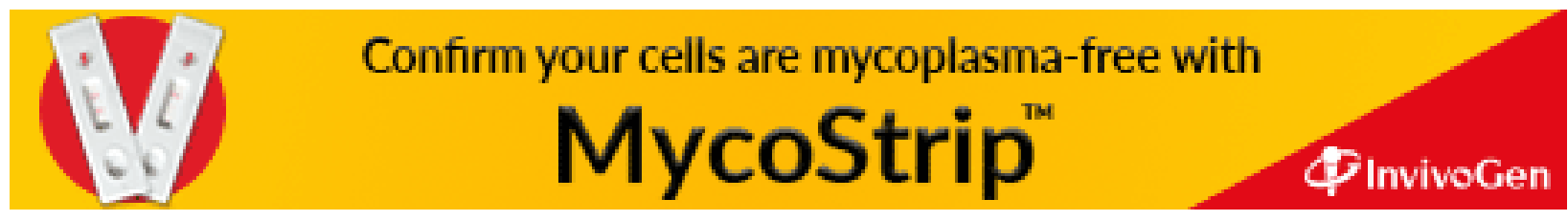

